AGH DRILLING, OIL, GAS • Vol. $34 \cdot$ No. $4 \cdot 2017$

http://dx.doi.org/10.7494/drill.2017.34.4.945

\author{
Marcin Kremieniewski*, Marcin Rzepka*, Stanisław Stryczek**, \\ Rafał Wiśniowski**
}

\title{
THE INFLUENCE OF ANTI-SEDIMENTATION AGENTS ON THE TECHNOLOGICAL PARAMETERS OF CEMENT SLURRY***
}

\section{INTRODUCTION}

The efficiency of insulating permeable zones between pipes and beyond them mainly depends on properly designed slurry. Significantly, the requirements for cement slurries are mainly conditioned by the number of tripped casing columns, geological-technical conditions, design of the well and its designation.

Cement slurries to be used for sealing boreholes in definite geological-technical conditions have specific physical properties, e.g. density, filtration, lack of shrinking during hydration. The cement sheath made of such slurry should have appropriate mechanical parameters and be impervious to gas. However, when sealing directional and horizontal boreholes attention should be paid to considerably stricter regimes for slurry parameters, i.e. sedimentation stability, water settling (free water) and the filtration of slurry. These are the most important parameters determining the usability of slurry for sealing directional boreholes $[2,10,13,18]$.

The number of additional factors influences this situation by directly improving the sedimentation stability of cement slurry, i.e. one of the most important factors contributing to efficient sealing of directional and horizontal boreholes.

\section{PARAMETERS DETERMINING THE SEDIMENTATION STABILITY OF CEMENT SLURRY DISPERSION}

When sealing casing columns, solid particles settle and the water settling effect takes place (Fig. 1). The values of these parameters increase with the increasing drift of the

\footnotetext{
* Oil and Gas Institute - National Research Institute, ul. Lubicz 25A, 31-503 Krakow, Poland

** AGH University of Science and Technology, Faculty of Drilling, Oil and Gas, Krakow, Poland

*** Paper was based on: Research work How to improve sedimentation stability of cement slurries - work of OGI-NRI on the order of Ministry of Science and Higher Education, Archival no: DK-4100/36/16, order no. 36/KW/16; Statutory research no. 11.11.190.555 task 2. realized at the Faculty of Drilling, Oil and Gas, AGH UST.
} 
borehole's axis from vertical. Those fractions of the slurry which are heavier than working water gravitationally drop down much faster than lighter ones. This phenomenon is observed mainly in the case of drilling muds containing weighting material. The fractioning of cement slurry in a vertical borehole takes place on much of its length, therefore this effect can hardly be detected. In directional or horizontal boreholes, the fractioning can be observed at a section of ten or so centimeters long, i.e. which sometimes equals to the diameter of the borehole. For this reason, the homogeneity of fresh slurry in directional and horizontal boreholes is very important $[5,11,13,17]$. Moreover, the sediment sealing slurry may have a lower density in the upper part of the borehole, which results in anisotropy of the hardened slurry. The cement sheath made of nonhomogeneous slurry will considerably vary (from one measuring point to another) in such parameters as mechanical strength, adhesiveness to steel tubes, porosity and permeability $[8,11,12,19]$. Also bearing in mind the higher values of water settlement in cemented annular space under the top part of wall of horizontal or strongly drifted borehole, we may assume that when the cement binds, this space will be a canal space (Fig. 2) for potential gas migration along the casing column on the cement/casing interface $[3,6,9,14]$.

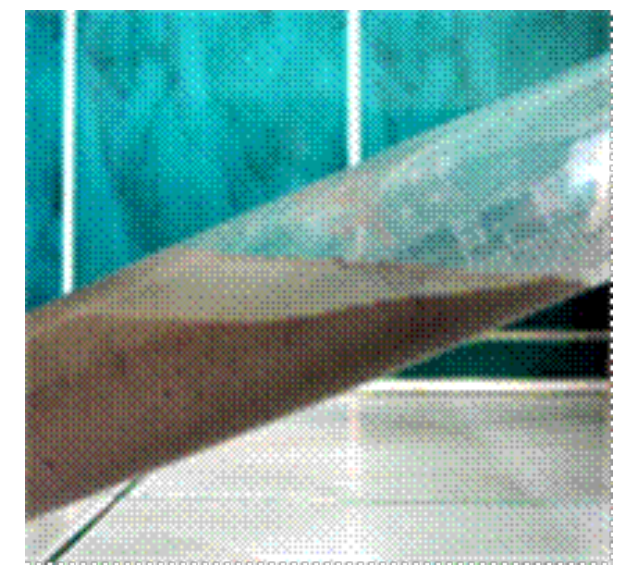

Fig. 1. Water settling in slurry having low sedimentation stability

The sedimentation stability of cement slurry is closely connected with the amount of working water in cement slurry, i.e. water/cement ratio. The amount and type of dispersing agent (liquefier) also plays an important role. For the sake of obtaining a uniform structure of liquid cement slurry, various fine-grain additives, admixtures or polymers are used to increase the viscosity of the dispersion $[11,12,16,20]$. Attention should be paid to the problems when designing the composition of a sedimentation-stable slurry, which will be so liquefied as to enable its pumping at low pressure, where the turbulent flow is possible. This inconvenience is connected with the fact that lowering of intermolecular attraction forces, thanks to which the liquidity of the slurry is improved, is connected with the free movement of fine fractions due to external forces $[1,6]$. Accordingly, the liquefied slurry tends to destabilize under the influence of the settling particles and precipitation of free water. When sealing directional and horizontal boreholes, attention is mainly paid to properties such as sedimentation stability, water settling (free water) and filtration of slurry. It should be emphasized that they 
are the most important parameters deciding about the efficiency of sealing of directional boreholes $[2,7,10]$. The sedimentation stability of cement slurry can be established with the use of different techniques. The most accurate ones lie in laser measurement of quantitative distribution of particles in a volume of fluid in the analyzed column at a given measuring point. In industrial conditions it is most frequently the amount of water precipitated over the cement slurry (water settling) which is measured. Owing to the fact that cement slurry may settle, and does not show water settlement, the measurement of the density of slurry in the sedimentation column is most efficient (photo 2). Based on the measurement of the density of the slurry in particular parts of the borehole (top, middle, bottom) we can determine the fractioning of the cement slurry dispersion.

The analysis of sedimentation allows for the determination of the homogeneity of the liquid slurry, though it is important to know that also other factors affect the fractioning of the slurry, i.e. :

- water settling (free water),

- density of cement slurry,

- rheological parameters of cement slurry,

- filtration of cement slurry,

- time of thickening and bounding of cement slurry $[8,12]$.

a)

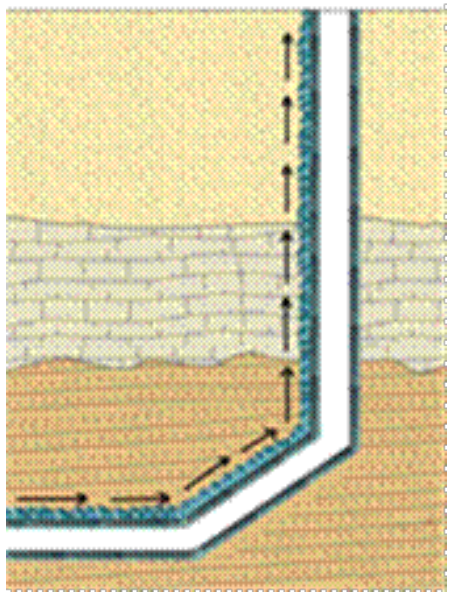

b)

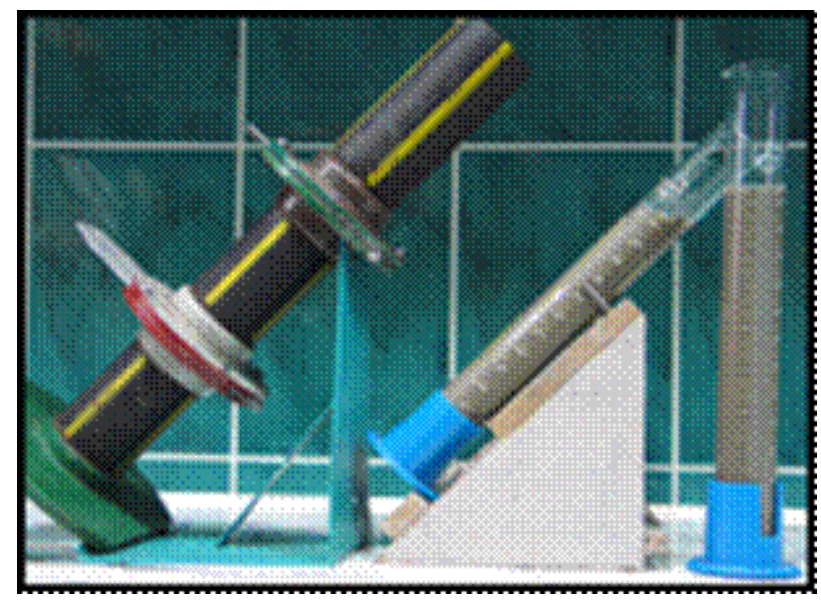

Fig. 2. Stand for determining sedimentation stability of cement slurry and water settling: a) sedimentation column; b) cylinder for water settling measurement

During the general interpretation of the above parameters, some kind of dependence between mentioned slurry properties can be observed. This is associated with the presence of cement slurry in the dispersion which contains a number of additives and admixtures playing different functions. Accordingly, each cement slurry should be treated individually, depending on its designation for specific geological-technical conditions. Moreover, applied additives and admixtures should be analyzed in view of their influence on the other technological parameters (except sedimentation stability), which is the subject of this publication. 


\section{RESEARCH WORK}

Research works on determining the influence of anti-sedimentation agents on the technological parameters of cement slurries were based on standards: PN-EN 10426-2 Oil and gas industry. Cements and materials for cementing boreholes. Part 2: Analysis of drilling cements and API SPEC 10 Specification for materials and testing for well cements.

The main purpose of laboratory experiments was to determine the quantitative and qualitative influence of anti-sedimentation admixtures on the technological parameters of cement slurry. The slurry recipes were analyzed for two borehole conditions: temperature $30^{\circ} \mathrm{C}$ and pressure $5 \mathrm{MPa}$, and $50^{\circ} \mathrm{C}$ and $18^{\circ} \mathrm{C} \mathrm{MPa}$, respectively. All recipes were based on drilling cement G HSR.

Base slurry was used for analyses (low sedimentation stability). Then the recipe was modified, i.e. various anti sedimentation admixtures were used in definite quantities (based on preliminary analyses). The type of applied agents, recipes of slurries, as well as quantities of particular additives and admixtures are listed in Tables 1 and 2, whereas the obtained technological parameters for the analyzed group of recipes are presented in Tables 3 and 4 .

Table 1

Recipes of cement slurries for borehole conditions: temp. $30^{\circ} \mathrm{C}$, pressure $5 \mathrm{MPa}$

Constant components: cement G HSR $=100 \%$, microcement $20.0 \%$, salinity of working water $\mathrm{KCl}=3.0 \%$ (bwow), defoamer $=0.3 \%$ (bwoc), swelling agent $=0.3 \%$ (bwoc)

\begin{tabular}{|c|c|c|c|c|c|c|c|c|c|c|c|}
\hline No. & $\begin{array}{l}\text { Composition (No.) } \\
\text { ratio }(\mathrm{w} / \mathrm{c})\end{array}$ & 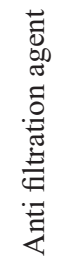 & 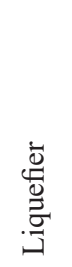 & 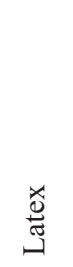 & 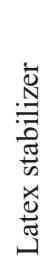 & 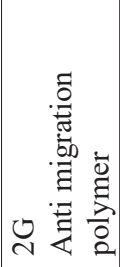 & 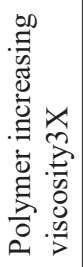 & 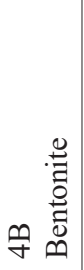 & 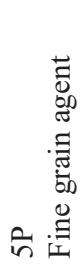 & 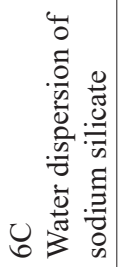 & 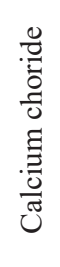 \\
\hline 1. & $\begin{array}{l}\text { No. } 1 \\
\mathrm{w} / \mathrm{c}=0.45\end{array}$ & 0.20 & 0.20 & 10.0 & 1.0 & - & - & - & - & - & 4.0 \\
\hline 2. & $\begin{array}{l}\text { No. } 2 \\
\mathrm{w} / \mathrm{c}=0.45\end{array}$ & 0.20 & 0.30 & 10.0 & 1.0 & 4.0 & - & - & - & & 4.0 \\
\hline 3. & $\begin{array}{l}\text { No. } 3 \\
\mathrm{w} / \mathrm{c}=0.45\end{array}$ & 0.20 & 0.35 & 10.0 & 1.0 & - & 0.15 & - & - & & 2.0 \\
\hline 4. & $\begin{array}{l}\text { No. } 4 \\
w / c=0.50\end{array}$ & 0.20 & 0.20 & 10.0 & 1.0 & - & - & 0.50 & - & - & 2.0 \\
\hline 5. & $\begin{array}{l}\text { No. } 5 \\
\mathrm{w} / \mathrm{c}=0.52\end{array}$ & 0.20 & 0.20 & 10.0 & 1.0 & - & - & - & 0.50 & - & 2.0 \\
\hline 6. & $\begin{array}{l}\text { No. } 6 \\
\mathrm{w} / \mathrm{c}=0.50\end{array}$ & 0.20 & 0.20 & 10.0 & 1.0 & - & - & - & - & 3.0 & 2.0 \\
\hline
\end{tabular}


Table 2

Recipes of cement slurries for borehole conditions: temp. $50^{\circ} \mathrm{C}$, pressure $18 \mathrm{MPa}$

Constant components: cement G HSR $=100 \%$, microcement $20.0 \%$, salinity of working water $\mathrm{KCl}=3.0 \%$ (bwow), defoamer $=0.3 \%$ (bwoc), swelling agent $=0.3 \%$ (bwoc)

\begin{tabular}{|c|c|c|c|c|c|c|c|c|c|c|c|}
\hline No. & $\begin{array}{l}\text { Composition (No.) } \\
\text { ratio }(\mathrm{w} / \mathrm{c})\end{array}$ & 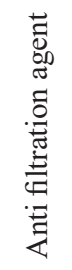 & 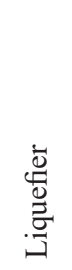 & 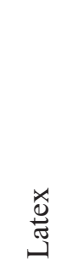 & 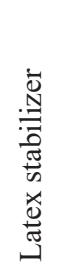 & 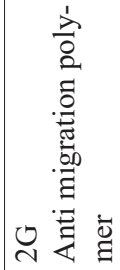 & 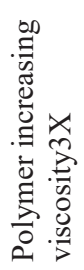 & œ & 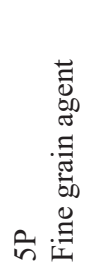 & 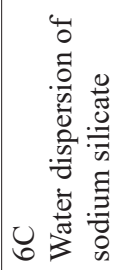 & 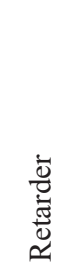 \\
\hline 1. & $\begin{array}{l}\text { No. } 7 \\
w / c=0.50\end{array}$ & 0.20 & 0.10 & 10.0 & 1.0 & - & - & - & - & - & 0.10 \\
\hline 2. & $\begin{array}{l}\text { No. } 8 \\
w / c=0.50\end{array}$ & 0.20 & 0.10 & 10.0 & 1.0 & 4.0 & - & - & - & & 0.10 \\
\hline 3. & $\begin{array}{l}\text { No. } 9 \\
w / c=0.50\end{array}$ & 0.20 & 0.10 & 10.0 & 1.0 & - & 0.15 & - & - & & 0.10 \\
\hline 4. & $\begin{array}{l}\text { No. } 10 \\
\mathrm{w} / \mathrm{c}=0.50\end{array}$ & 0.20 & 0.10 & 10.0 & 1.0 & - & - & 0.50 & - & - & 0.10 \\
\hline 5. & $\begin{array}{l}\text { No. } 11 \\
\mathrm{w} / \mathrm{c}=0.50\end{array}$ & 0.20 & 0.10 & 10.0 & 1.0 & - & - & - & 0.50 & - & 0.10 \\
\hline 6. & $\begin{array}{l}\text { No. } 12 \\
\mathrm{w} / \mathrm{c}=0.50\end{array}$ & 0.20 & 0.20 & 10.0 & 1.0 & - & - & - & - & 3.0 & 0.20 \\
\hline
\end{tabular}

Technological parameters were analyzed for a group of 12 slurries presented in Table 1 (six recipes for temperature $30^{\circ} \mathrm{C}$ and $50^{\circ} \mathrm{C}$ ). The obtained results are listed in Table 2 .

The rheological parameter, determined with a rotary viscometer Ofite 900 , were analyzed. The dependence between tangential stresses $(\tau i)$, and shear rates $(\bar{\gamma})$ were defined. The plastic viscosity and yield point were established and the obtained results presented in Table 2.

The filtration of cement slurries in dynamic conditions was determined with a filtration press HPHT 7120 by Chandler. The thickening time of the analyzed slurries was defined with a pressure consistometer OFITE 130. On this basis, the change of consistency could be measured and the time of the thickening of cement slurry determined.

The first group of slurries were designed for sealing casing columns seated at a depth of about $200 \mathrm{~m}$ to about $800 \mathrm{~m}$, and sealed at a temperature of $30^{\circ} \mathrm{C}$ and pressure $5 \mathrm{MPa}$. These slurries were based on drilling cement G HSR. The analysis of the obtained results reveals that the density of slurries varied from $1800 \mathrm{~kg} / \mathrm{m}^{3}$ (slurry with admixed fine grained 5P) to $1885 \mathrm{~kg} / \mathrm{m}^{3}$ base slurry 1 Baz (Fig. 3). The analysis of sedimentation stability of the analyzed slurries shows that fractioning could be observed only in base slurry 1 , in the remaining cases the required sedimentation stability was obtained. 


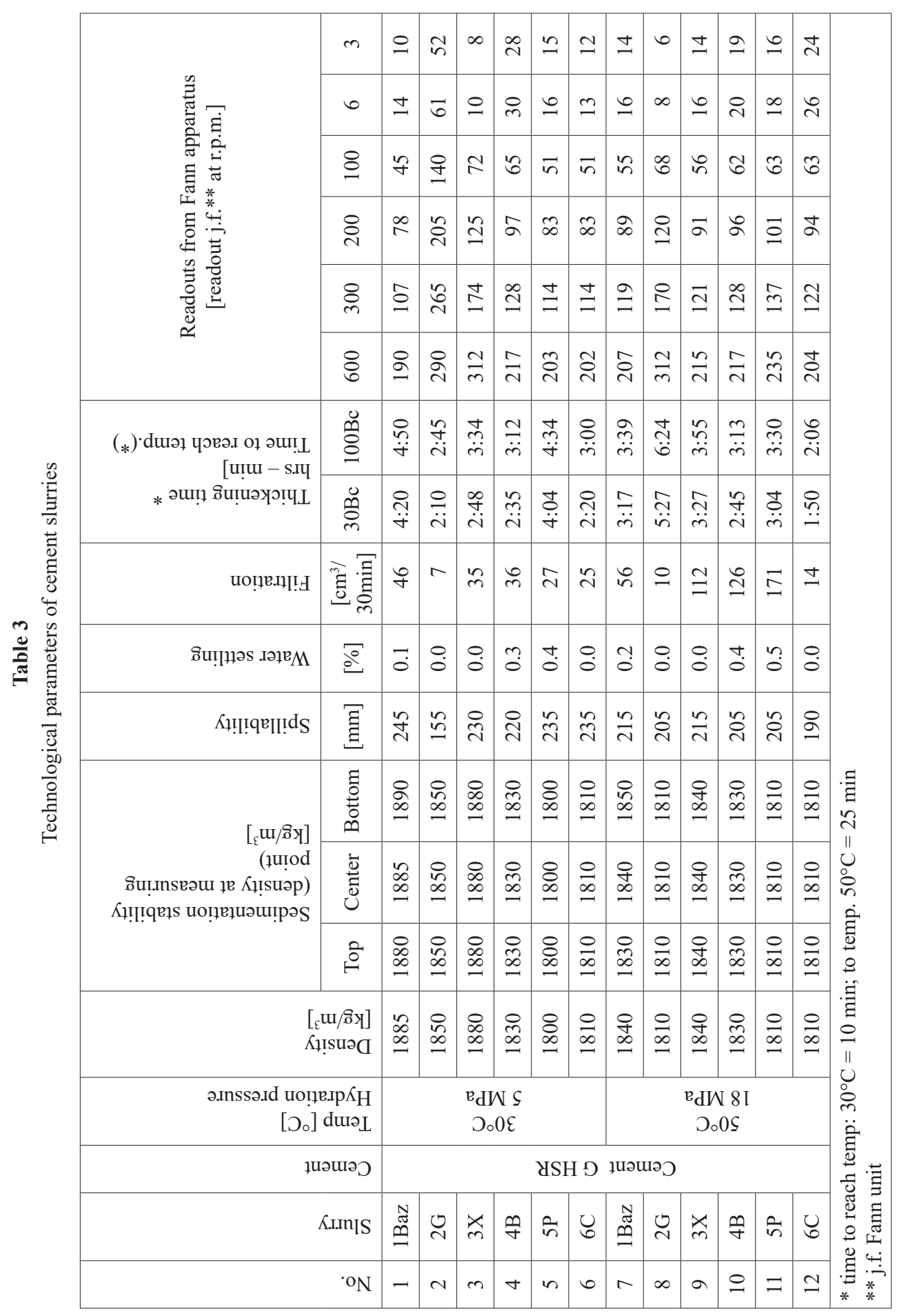




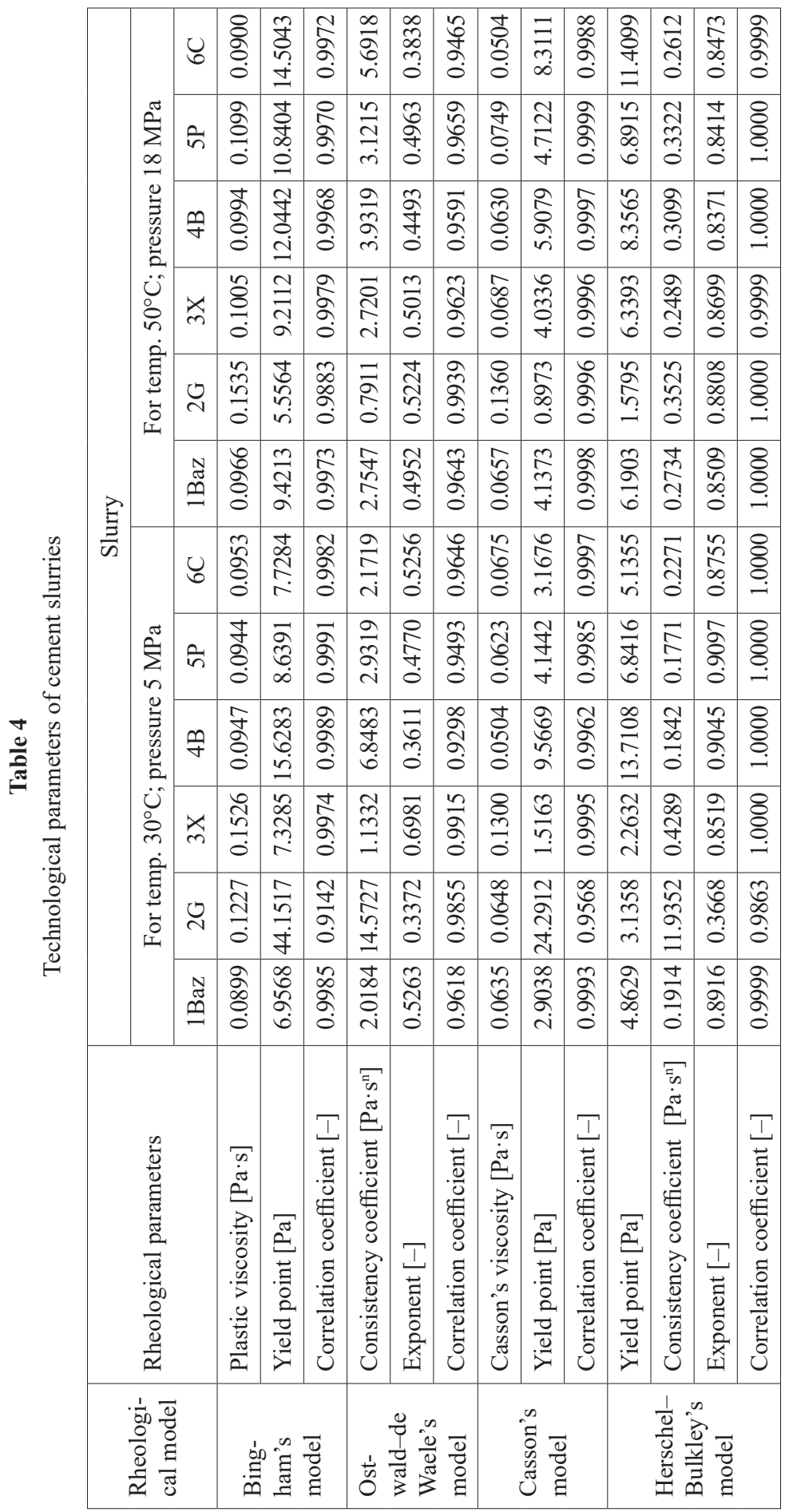


The spillability was observed to considerably decrease (Tab. 3) in slurry 2G (admixture of anti migration polymer), which is connected with a considerable increase of consistency coefficient $_{\mathrm{HB}}$ (Fig. 5). The filtration in this slurry is lowest $\left(7.2 \mathrm{~cm}^{3} / 30 \mathrm{~min}\right)$ and the thickening time is short ( $2 \mathrm{hrs} .10 \mathrm{~min}$ for $30 \mathrm{Bc}^{1}$, and $2 \mathrm{hrs} .45 \mathrm{~min}$ for $100 \mathrm{Bc}$ ). With this information in mind, the anti migration agent $2 \mathrm{G}$ lowers filtration, water settling and considerably increases rheological parameters of the slurry. This can be caused by the presence of a suspension based on working water and its increased viscosity. This and the necessity to additionally liquefy the slurry should be accounted for when designing the slurry. In the analyzed group of recipes (Tab. 3) we can observe a favorable operation of anti sedimentation admixtures on the stability of cement slurry. However, during complex analysis of technological parameters the admixture of 4B and 5P resulted in a higher water settlement. An excessive value of water settling may stem from the use of fine fractions, which cause a slight increase of the yield point ${ }_{\mathrm{HB}}$ (Fig. 5) and anti sedimentation activity; however in the top part of the measuring column it may slightly settle gravitationally, forming a visible water film on the slurry surface. The filtration in these slurries is at the required level (below $\left.50 \mathrm{~cm}^{3} / 30 \mathrm{~min}\right)$.

In the second group are slurries designed for sealing casing columns at a depth of about $800 \mathrm{~m}$ to $1300 \mathrm{~m}$, sealed at a temperature of $50^{\circ} \mathrm{C}$ and pressure $18 \mathrm{MPa}$. The slurries were also based on drilling cement G HSR. The density of these slurries oscillated between 1810 $\mathrm{kg} / \mathrm{m}^{3}$ (slurry with $2 \mathrm{G}, 5 \mathrm{P}, 6 \mathrm{C}$ ) to $1840 \mathrm{~kg} / \mathrm{m}^{3}$ (base slurry $1 \mathrm{Baz}$ and $3 \mathrm{X}$ ). In this group of slurries the required sedimentation stability was obtained after using admixtures. The fractioning was noted only in the base slurry. The analysis of the influence of the applied admixtures on the rheological parameters of the analyzed slurries shows the similar values of the rheological parameters (Fig. 5). A slight increase of the rheological parameters (plastic viscosity ${ }_{\mathrm{Css}}$ and consistency coefficient ${ }_{\mathrm{HB}}$ ) was visible only after applying admixture $2 \mathrm{G}$, which also in the previous group of slurries increased the values of rheological parameters. The use of these admixtures also lowered filtration from $56 \mathrm{~cm}^{3} / 30 \mathrm{~min}$ (base slurry) to $10 \mathrm{~cm}^{3} / 30 \mathrm{~min}$ (slurry with $2 \mathrm{G}$ ) - Table 3, Figure 5. However, in this group of slurries the admixture $2 \mathrm{G}$ (Fig. 4) strongly elongated the time of thickening ( 5 hrs. 27 min for $30 \mathrm{Bc}$ and $6 \mathrm{hrs} .24 \mathrm{~min}$ for $100 \mathrm{Bc}$ ). Such behavior can be explained by the synergy of the anti-migration agent $2 \mathrm{G}$ and the applied thickening retarder. In the analyzed group of slurries the addition of fine grain admixtures $4 \mathrm{~B}, 5 \mathrm{P}$ caused a considerable $\left(126 \mathrm{~cm}^{3} / 30 \mathrm{~min}\right.$ and $171 \mathrm{~cm}^{3} / 30 \mathrm{~min}$, respectively) increase of filtration. The application of a polymer increasing viscosity $3 \mathrm{X}$ caused a higher filtration from $56 \mathrm{~cm}^{3} / 30 \mathrm{~min}$ in base slurry $1 \mathrm{Baz}$ to $112 \mathrm{~cm}^{3} / 30 \mathrm{~min}$ in a slurry containing $3 \mathrm{X}$. These effects can be caused by the incompatibility of the administered admixtures and the retarder. These recipes should be additionally modified to reduce the filtration of the slurry. Analogous to the previous group of slurries, the fine grain admixtures 4B and 5P resulted in the slight precipitation of free water.

The analyses in hardened cement slurries covered mechanical parameters, i.e. compressive strength, adhesiveness to steel pipes, porosity and permeability. Strength analyses were performed with Chandler 4207. This machine allowed for static tests of bending, compression and adhesiveness of cement stone to various surfaces to be conducted. Experiments on the microstructure of hardened sealing slurries were realized with a mercury porosimeter MicroMetrics.

\footnotetext{
$\mathrm{Bc}-$ unit of Bearden's consistency of slurry while measuring time of thickening in consistometer
} 


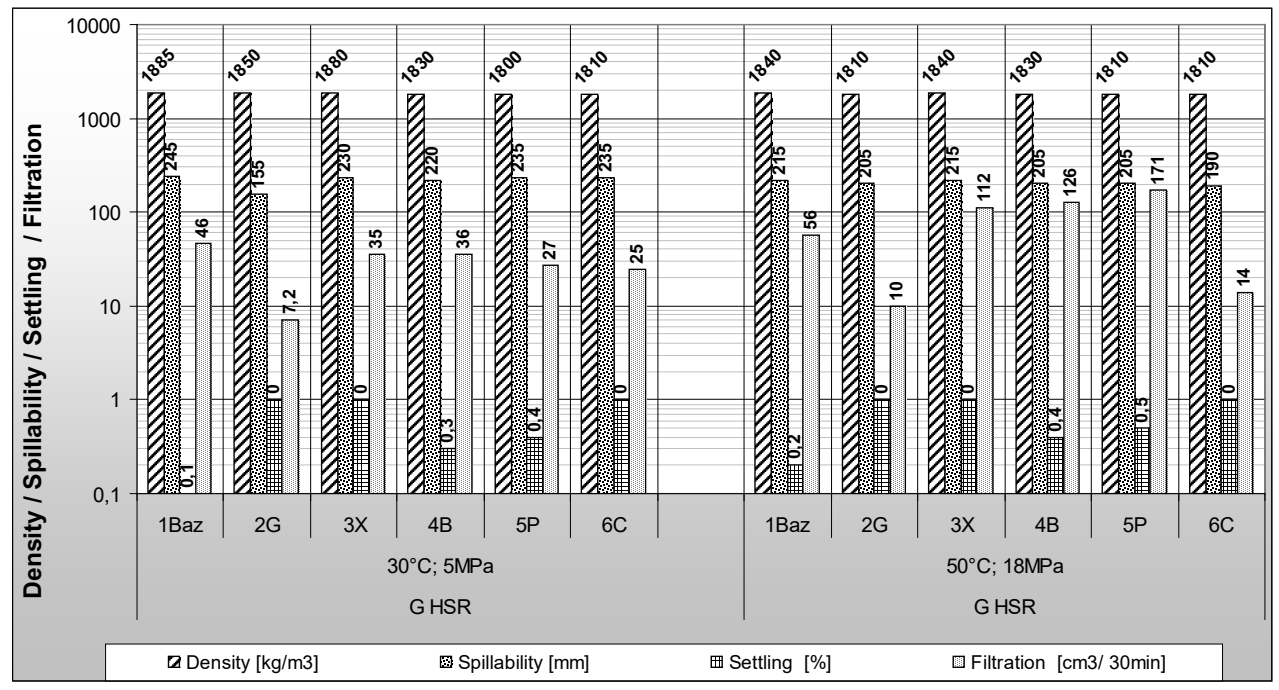

Fig. 3. Density, spillability, settling and filtration of cement slurries

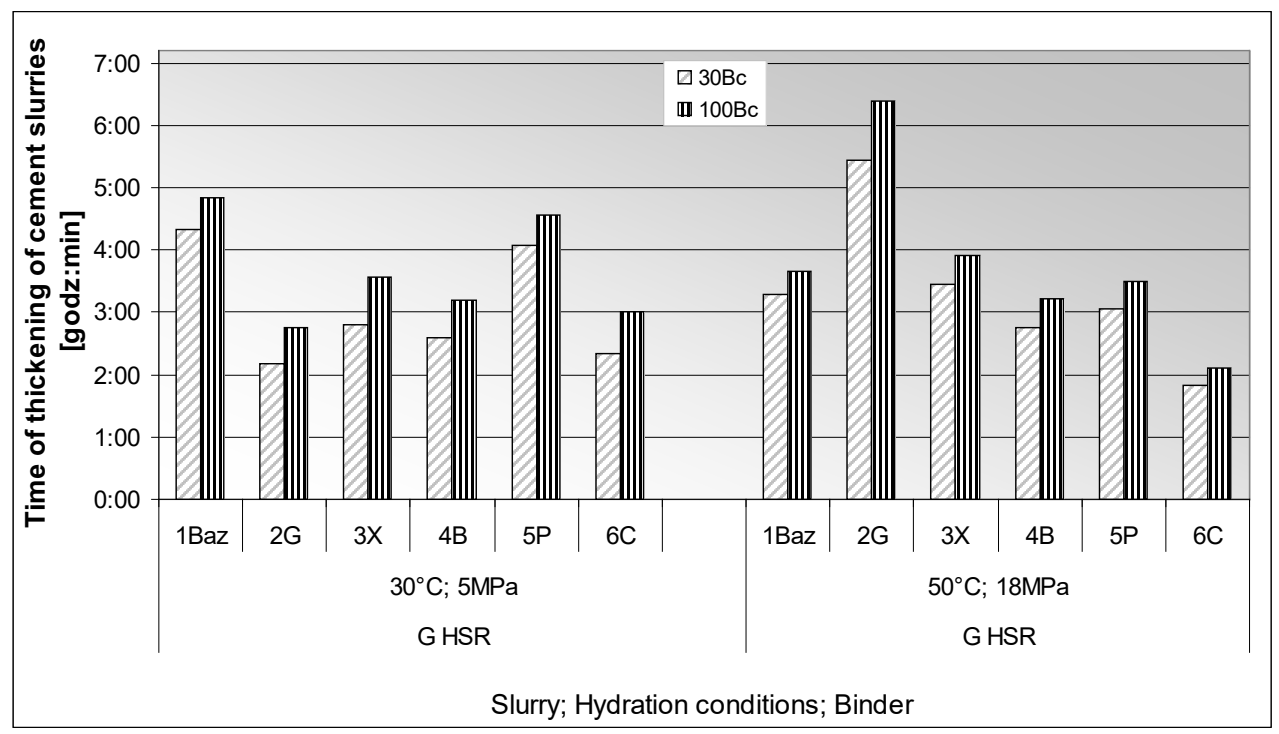

Fig. 4. Measurements of time of thickening of cement slurries

The analyses of hardened sealing slurries were mainly focused on mechanical parameters and porosity, which describe the microstructure of hardened cement slurry. Comparing the obtained strength results on compression in a group of slurries to be applied at temperature $30^{\circ} \mathrm{C}$ and pressure $5 \mathrm{MPa}$, we can observe an increase of compressive strength and adhesiveness to steel pipes after applying admixture 6C (Tab. 4). 


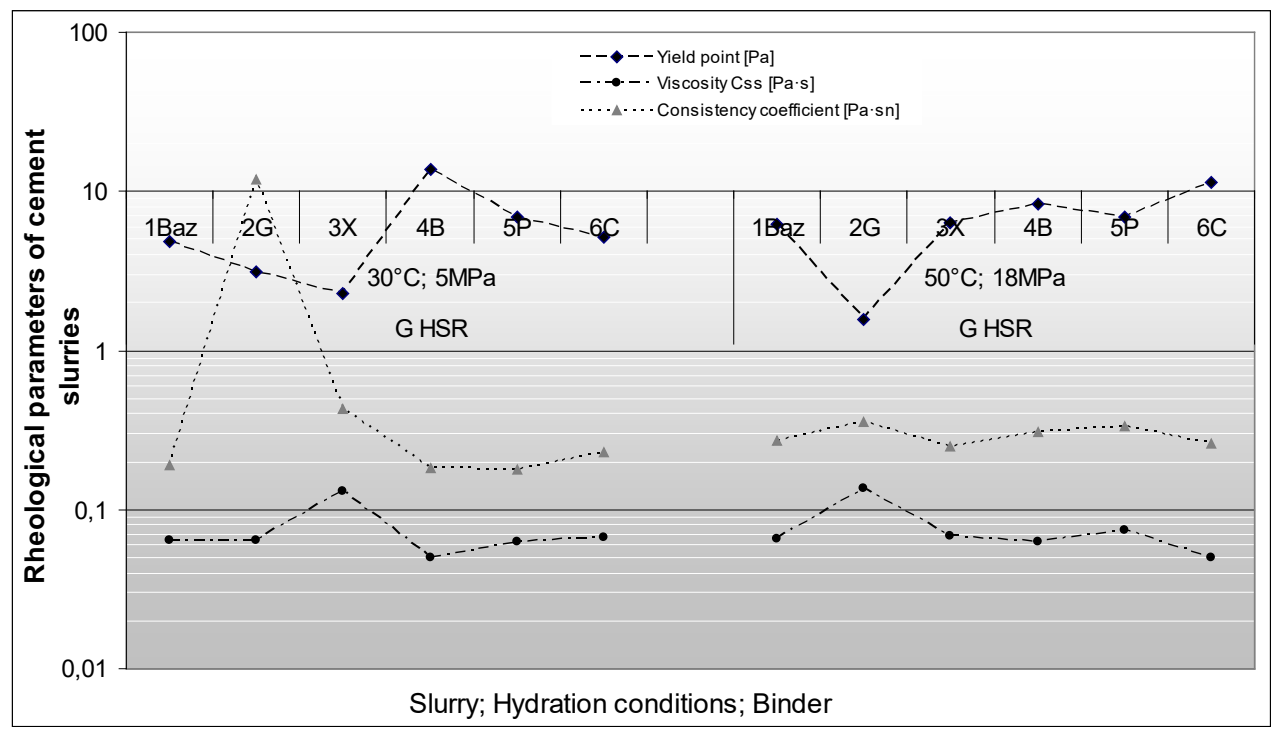

Fig. 5. Results of the measurement of the rheological parameters of cement slurries

Table 4

Mechanical parameters of hardened slurries

\begin{tabular}{|c|c|c|c|c|c|c|c|c|c|c|}
\hline \multirow{4}{*}{ 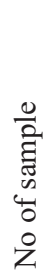 } & \multirow{4}{*}{ 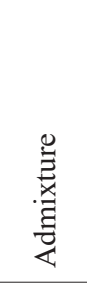 } & \multirow{4}{*}{ 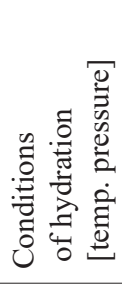 } & \multicolumn{8}{|c|}{ Analyzed parameter of hardened slurry } \\
\hline & & & \multicolumn{3}{|c|}{$\begin{array}{c}\text { Compressive strength } \\
{[\mathrm{MPa}]}\end{array}$} & \multicolumn{3}{|c|}{$\begin{array}{c}\text { Adhesiveness to steel } \\
\text { tubes } \\
{[\mathrm{MPa}]}\end{array}$} & $\begin{array}{c}\text { Perme- } \\
\text { ability } \\
{[\mathrm{mD}]}\end{array}$ & $\begin{array}{c}\text { Porosity } \\
{[\%]}\end{array}$ \\
\hline & & & \multicolumn{8}{|c|}{ Hydration time } \\
\hline & & & 2 days & 7 days & 28 days & 2 days & 7 days & 28 days & \multicolumn{2}{|c|}{28 days } \\
\hline 1 & $1 \mathrm{Baz}$ & \multirow{6}{*}{$\begin{array}{c}30^{\circ} \mathrm{C} \\
5 \mathrm{MPa}\end{array}$} & 9.3 & 11.6 & 13 & 6.2 & 7.5 & 8.7 & 0.12 & 37.15 \\
\hline 2 & $2 \mathrm{G}$ & & 10.1 & 10.9 & 12.3 & 4.9 & 5.1 & 8.5 & 0.05 & 35.15 \\
\hline 3 & $3 X$ & & 10.6 & 11.2 & 11.9 & 3.8 & 5.9 & 7.5 & 0.07 & 35.81 \\
\hline 4 & 4B & & 9.8 & 11.9 & 12.6 & 5 & 5.5 & 6.5 & 0.16 & 36.22 \\
\hline 5 & $5 \mathrm{P}$ & & 9 & 11.4 & 11.8 & 5.1 & 6.8 & 8.6 & 0.09 & 39.42 \\
\hline 6 & $6 \mathrm{C}$ & & 11.3 & 14.1 & 14.8 & 6.8 & 9 & 9.7 & 0.09 & 36.87 \\
\hline 7 & $1 \mathrm{Baz}$ & \multirow{6}{*}{$\begin{array}{c}50^{\circ} \mathrm{C} \\
18 \mathrm{MPa}\end{array}$} & 16.4 & 16.8 & 17.2 & 6.8 & 7.9 & 9.1 & 0.14 & 36.92 \\
\hline 8 & $2 \mathrm{G}$ & & 11 & 13.6 & 14.1 & 5.9 & 6.1 & 8.8 & 0.07 & 35.55 \\
\hline 9 & $3 X$ & & 12.8 & 13.7 & 14.3 & 4 & 6.9 & 8.7 & 0.09 & 35.77 \\
\hline 10 & $4 B$ & & 11.3 & 12.4 & 12.7 & 6.9 & 6.5 & 7.3 & 0.08 & 35.67 \\
\hline 11 & $5 \mathrm{P}$ & & 8.6 & 11.4 & 12.1 & 4.1 & 5.8 & 7 & 0.15 & 38.88 \\
\hline 12 & $6 \mathrm{C}$ & & 9.3 & 12.3 & 12.7 & 6.2 & 7.8 & 8.5 & 0.12 & 36.75 \\
\hline
\end{tabular}


Such results can be explained by hydration reinforced by an admixture of water dispersion of sodium silicate. The comparison of the parameters describing the microstructure of the sample (porosity, permeability) shows that the strongest sealing of hardened cement slurry matrix was obtained after admixing anti migration polymer $2 \mathrm{G}$ (Tab. 4).

In the second group of slurries, the mechanical parameters were observed to slightly lower after applying agents improving sedimentation stability. This may be the reason to carry on modifications of the recipes. However the microstructure of the hardened slurry was improved as in the previous group of slurries. It resulted in the lowering permeability to gas and porosity after using admixture $2 \mathrm{G}$. The results of analyses of mechanical parameters are listed in Table 5 .

Concluding, anti sedimentation admixtures show a considerable influence on the technological parameters of cement slurry. Various types of admixture improve the sedimentation stability and also have an influence on the remaining parameters of cement slurry. The analyses confirm the very differentiated advantageous and disadvantageous operation of the applied agents. The use of fine grain admixtures favorably lowers the sedimentation of the slurry, but may also increase water settling and filtration. The use of an anti-migration polymer may result in higher rheological parameters of slurry and lower filtration and water settling, which is advantageous in view of anti sedimentation activity. However this agent may significantly elongate the thickening time. This should be accounted when planning slurry for given borehole conditions.

\section{CONCLUDING REMARKS}

The following conclusions can be drawn from the obtained results of laboratory analyses:

- Some anti sedimentation admixtures (3X, 4B, 5P) advantageously influence the stability of slurry, but also may increase water settling and the filtration of slurry. This means that additional anti filtration agents have to be applied.

- Admixtures counteracting the sedimentation of slurry increase the viscosity of working water and slurry. The effect of the above is stronger counteracting forces of gravity affecting the heavier fractions in the cement slurry.

- The increase of plastic viscosity of cement slurry by using anti sedimentation admixture may lower pumpability, and so increase the pumping pressure. This is important for obtaining the required turbulent flow.

- Because of the increase of rheological parameters due to the applied anti sedimentation admixtures, sometimes a liquefier has to be used to lower the rheological parameters, maintaining the required sedimentation stability.

- The agents improving stability of slurry may sometimes result in a visible (over three times) increase of filtration. This behavior of admixtures prompts their further detailed analyses.

- The use of anti-sedimentation admixtures results in a homogeneous structure of the cement sheath. This is confirmed by lower permeability and porosity values in samples (admixture of 2G).

- Owing to the indicated significant influence of anti-sedimentation admixtures on the technological parameters of cement slurries, recipes modified with agents improving sedimentation stability should be analyzed laboratorily on specialist apparatuses each time. 


\section{REFERENCES}

[1] Aguilera R. et al.: Horizontal Wells. Gulf Publishing Company, Houston 1991.

[2] Armessen P., Jourdan A.P., Mariotti Ch.: Horizontal drilling gas negative and positive factors. PennWell Publishing Comp., 1988.

[3] Bandrowski J., Merta H., Zioło J.: Sedymentacja zawiesin. Zasady i projektowanie. Wydawnictwo Politechniki Śląskiej, Gliwice 1995.

[4] Bhatty J.I., Banfill P.F.G.: Sedimentation behaviour in cement pastes subjected to continuous shear in rotational viscometers. Cement and Concrete Research 1982.

[5] Barron A.R.: Hydratation of Portland Cement, http://cnx.org/content/m16447/latest/ [26.01.2010].

[6] Carpenter R.B.: Matrix Control Cementing Slurry. U.S. Patent No. 4.569.395, 1986.

[7] Chatterji S.: On the properties of freshly made Portland cement paste. Part 2: Sedimentation and strength of flocculation. Cement and Concrete Research, 1988.

[8] Dohnalik M., Zalewska J.: Korelacja wyników laboratoryjnych uzyskanych metoda rentgenowskiej mikrotomografi, jądrowego rezonansu magnetycznego i porozymetrii rtęciowej. Nafta - Gaz, nr 10, 2013, pp. 735-743.

[9] Dębińska E.: Ocena działania dodatków opóźniających czas wiązania zaczynów cementowych na podstawie badań laboratoryjnych. Nafta - Gaz 2012, nr 4, pp. 225-232.

[10] Kątna Z. et al.: Badania modelowe wpływu odstoju wody, sedymentacji i poczatkowego skurczu zaczynu cementowego na jakość uszczelniania rur w otworach odchylonych od pionu i poziomych w temperaturach do 85 ${ }^{\circ}$ C. Praca naukowo-badawcza INiG, Kraków 1997.

[11] Kremieniewski M., Stryczek S., Kotwica Ł.: Zmiany w mikrostrukturze plaszcza cementowego w zależności od warunków hydratacji zaczynu. Nafta - Gaz, nr 12, 2014, pp. 918-926.

[12] Kremieniewski M., Rzepka M., Stryczek S., Wiśniowski R., Kotwica Ł., Złotkowski A.: Korelacja przepuszczalności i parametrów opisujących strukturę stwardniałych zaczynów cementowych stosowanych do uszczelniania otworów w rejonie Basenu Pomorskiego. Nafta - Gaz, nr 10, 2015, pp. 737-746.

[13] McNaught A.D., Wilkinson A.: IUPAC. Compendium of Chemical Terminology (Gold Book). Wyd. 2. Oxford: Blackwell Scientific Publications, 1997. Wersja internetowa: M. Nic, Jirat J., Kosata B.: Colloidal dispersion (ang.), aktualizowana przez A. Jenkins. DOI: 10.1351/goldbook.C01174.

[14] Parcevaux P.: Gas Migration and GASBLOCK Technology. Driling \& Pumping, Aug. 1987, pp. 11-22.

[15] Rzepka M., Stryczek S., Laboratoryjne metody określania parametrów technologicznych świeżych zaczynów uszczelniajacych przed zabiegiem zwiazanym z procesem uszczelniania kolumn rur okładzinowych w otworach wiertniczych. Wiertnictwo, Nafta, Gaz, t. 25, z. 2, 2008, pp. 625-636.

[16] Slomkowski S. et. al.: Terminology of polymers and polymerization processes in dispersed systems (IUPAC Recommendations 2011). Pure and Applied Chemistry, vol. 83(12), 2011, pp. 2229-2259, DOI: 10.1351/PAC-REC-10-06-03.

[17] Stryczek S., Wiśniowski R., Gonet A., Złotkowski A.: The influence of time of rheological parameters of fresh cement slurries. AGH Drilling, Oil, Gas, vol. 31, no. 1, 2014, pp. 123-133. 
[18] Stryczek S., Wiśniowski R., Gonet A., Ferens W.: Parametry reologiczne świeżych zaczynów uszczelniajacych $w$ zależności od czasu ich sporządzania. Wiertnictwo, Nafta, Gaz, t. 26, nr 1-2, 2009, pp. 369-382.

[19] Wiśniowski R., Stryczek S., Skrzypaszek K.: Kierunki rozwoju badań nad reologia płynów wiertniczych. Wiertnictwo, Nafta, Gaz, nr 24, 2007, pp. 595-607.

[20] Zima G.: Nowy rozkład płuczki wiertniczej do zastosowania w warunkach HTHP. Nafta - Gaz, 2015, nr 8, pp. 556-564.

[21] Rzeczpospolita tupkowa. Studium wiedzy o gazie z formacji łupkowych. Prace Naukowe INiG nr 183, Kraków 2012. 